\title{
A Preliminary Investigation into the Annual Rainfall Trend and Patterns for Selected Towns in Parts of South-Eastern Nigeria
}

\author{
AFANGIDEH, A. I. \\ GEOGRAPHY AND REGIONAL PLANNING DEPARTMENT \\ UNIVERSITY OF CALABAR, NIGERIA \\ E-mail: idehidehak@yahoo.com \\ FRANCIS, E. OKPILIYA \\ GEOGRAPHY AND REGIONAL PLANNING DEPARTMENT \\ UNIVERSITY OF CALABAR, NIGERIA \\ EJA, E. I. \\ GEOGRAPHY AND REGIONAL PLANNING DEPARTMENT \\ UNIVERSITY OF CALABAR, NIGERIA \\ E-mail: ejako2007@yahoo.com
}

\begin{abstract}
Thirty - five (35) years (1971-2006) annual rainfall figures from three towns in Humid South-eastern Nigeria have been analysed for climatological baseline pattern and trend. Rainfall is choosen based on its importance while Calabar, Uyo and Umuiahia have synoptic stations with standard instruments and trained personnel hence reliable data. Rainfall is characteristically Humid with very high annual totals and ranges etc. There is statistically significant association of the baseline descriptive parameters and the region $\left(\mathrm{x}_{\mathrm{c}}{ }_{\mathrm{c}}>\mathrm{x}_{\mathrm{t}}{ }_{\mathrm{t}}=3759.96>\right.$ 16.8 ) at $99 \%$ confidence. No particularly clear fluctuating patterns or periodicities but trend analysis with the least square regression model suggest significantly declining trends for Uyo and Umuiahia. And have been statistically modeled for predictive and scientific management purposes as; $\mathrm{Y}=3191.23-36.16 \mathrm{x}+\mathrm{e}$ and; $\mathrm{Y}=$ $2955.20-31.50 \mathrm{x}+\mathrm{e}$ respectively. Annual rainfall projections up to year 2015 have been carried out while further studies with urbanization and transportation as well as potential impacts in the area are suggested.
\end{abstract}

Keywords: Annual rainfall, Trend analysis, Rainfall regime and variability

\section{Introduction and Problem}

Generally, the study of the weather and climatic elements of a region is vital for sustainable development of agriculture and planning. Particularly, rainfall and temperature temporal analyses for trends, fluctuations and periodicities are deemed necessary as such can indirectly furnish the "health" status of an environment. A declining and/or rising trend etc may be quite instructive for different segments of the human and natural systems. Impending long or short term weather - related natural disasters for instance may be predicted and better mitigative or adaptive actions initiated through the analysis of the fluctuations and return periods of the series. Extreme weather events that can lead to drought and prolonged heat spell; flooding etc can be assessed through the statistical analysis of a region's temporal rainfall regime. The global concern on the apparent deterioration in all of the earth's natural systems, particularly the weather and climate sub-system and global warming with attendant climate change pandemic renders credence to trend and periodicity analyses of weather elements. When carried out with the exponential growths in the human population, industrialization and urbanization etc, the picture is always threatening for man on earth. (World Bank, 1994; WMO, 1990). This baseline statistical analysis of the annual rainfall regime (1971-2006) for south eastern Nigeria is essential for planned policy formulations and strategies for sustainability in the long term.

\section{Research Aim and Objective}

The main aim of this work is to establish the trend and distributional pattern of the annual rainfall regime in the three study areas. For the attainment of the main goal, are the following specific objective:-

1) Define, statistically, the annual rainfall temporal trend and fluctuations as strategic planning tools;

2) Determine the baseline rainfall geographic pattern of the sub-region;

3) Examine policy implications for sustainability and climate change

\section{Conceptual Framework}

This study is anchored on the concept of climatic variability- postulates that the global weather and climate is given to variations and/or fluctuations because of the dynamic meteorological factors controlling periodically the character and manifestation of the weather and climatic elements worldwide. On a global scale however such much dynamic features include the Rossby Waves, feature the Anti cyclonic and cyclonic systems and the major winds system etc (Ayoade, 1986, Barry and Charley, 1981). 
In the West African sub region however such dynamic controls include the Inter Tropical Discontinuity (ITD), the semi permanent Sub Tropical Anti-cyclone (STA) and the main low level winds and disturbance features etc (Adedokun, 1978, 1981, Adefolalu, 1981 a and b; Anyadike, 1977). The Inter Tropical Discontinuity (ITD) is the meteorological meeting point of the south west monsoon and the northeast trade wind in West Africa. Its average latitudinal locations season after season north of the equator to a large extent determines the intensity and coverage of the monsoon rains or the hamarttan as the may be. Usually the ITD fig 1, oscillates between latitudes $17 / 19$ and $4 / 5^{\circ}$ North of the equators. As one of the two major dynamic features of the northern summer in the area, the ITD literally holds back the surging Trades resulting in the variability of the rainfall. The Sub-Tropical Anticyclone (STA) usually north of the ITD depicts the semi permanent high pressure system, in the Sahara, that influences the North-easterlies hence the dry season's weather. Located theoretically at about $30^{\circ}$ north, the fair weather system indirectly determines the coverage of the annual rainfall as it limits the Pole-ward movements of the ITD. In other years, the reverse may be the case with more area coverage and intensity of the rains. It is however the main dynamic system controlling the dry season weather and the harmattan in the region.

Annual rainfall in the study area can vary or fluctuate finally due to the character of the prevailing maritime surface winds during the northern summers. The main moisture bearing wind system is the South West Trades with source region in the South Atlantic. It begins as the south easterlies at about latitude $30^{\circ}$ south to become the South westeies (fig 1 refer).

On crossing the Equator in abeyance of the corrrilis principle. Being of maritime origin and track it deposits the moisture in the sub region between the months of April through October. A weakening or intensification of the South west trades, everything being equal, is expected to result in the annual rainfall fluctuations or variability.

\section{Research Methodology}

\subsection{Data Source and Type:}

Secondary rainfall data in years for 35 years (1971-2006) were obtained from the archives of Nigeria Meteorological Services Departments in Uyo, Calabar and Umnahia. Availability and reliability of the annual rainfall data, were considered foremost as these locations are longstanding operational synoptic stations, standard equipments and personnel; data gathered is therefore high grade. The meteorological office rain quage $\mathrm{mk}_{2}$ was use for routine observation involving measurements of amount of precipitation for periods of one to 24 hours. Rainfall is collected in a bottle placed in a removable copper bucket. The bottle facilitates handling and pouring and reduces loss by evaporation and unsetting. The bucket ensures retention for measurement of exceptionally heavy rainfall which may overflow from the bottle into the bucket. Rainfall is measured in millimeters with eight observations for a 24 hour period.

\subsection{Data Analytical Procedures}

Several descriptive statistics comprising the mean, standard deviation, range etc were used for descriptions and comparisons. Trend analysis was accomplished with the line graphs as well as the least square regression technique for hypotheses testing and modelling. The chi-square test of association where there are two or more sets of variables for comparison are use for ascertaining homogeneity of baseline indices.

Though time - series data are not bivariate data, a linear trend line can be obtained by using the simple regression analysis technique (Udofia, 2004, Okoko, 21001). In the study therefore, time in years is one independent variable (x) while annual rainfall amount for 35 years (1971-2006) is considered the dependent variable (y). The least square model is presented as;

$$
\begin{aligned}
& \mathrm{Y}=\mathrm{a}+\mathrm{bx}+\mathrm{e} \text { where; } \\
& \mathrm{Y}=\text { Dependent variable (annual rainfall in } \mathrm{mm} \text { ) } \\
& \mathrm{X}=\text { Independent variable (time in years). } \\
& \mathrm{a}=\text { A constant and } \mathrm{y}-\text { intercept } \\
& \mathrm{b}=\text { Regression coefficient } \\
& \mathrm{c}=\text { Error random term }
\end{aligned}
$$

Time in years was the only considered cause of the fluctuations as the meteorological controls of the annual rainfall vary in their positions and intensities periodically.

The contingency test, $\mathrm{k}$ - sample chi-square test of homogeneity is employed to associate the rainfall descriptive indices with the study area. The study was to establish whether there is significantly a variation in the indices having similar background. The problem can be solved as a $5 \times 3$ contingency problem utilizing the rather normal chi-square test formula. The use of the conventional $x^{2}$ formula involves the calculation of the expected frequencies using the formula.

$$
\mathrm{Fe}=\frac{\mathrm{FrFc}}{\mathrm{N}}
$$

Where: 
$\mathrm{Fe}=$ Expected frequency

$\mathrm{Fr}=$ Total row frequency

$\mathrm{Fc}=$ Total column frequency

$\mathrm{N}=$ Total frequency

The complete elements of the usual chi-square test is given below as;

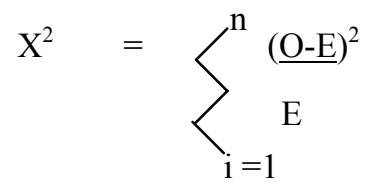

where

$\mathrm{O}=$ Observed frequency

$\mathrm{E}=$ Expected frequency

$\mathrm{n}=$ Number of categories

\subsection{Hypothesis Formulation}

The following research hypothesis are formulated a prior for testing at $99 \%$ level of confidence.

$\mathrm{H}_{\mathrm{i}}$ : Annual rainfall regimes have varied significantly over time in the study area

$\mathrm{H}_{0}$ : It has not

$\mathrm{H}_{2}$ : The annual rainfall descriptive indices are averagely the same coming from a theoretical homogenous climatic region.

$\mathrm{H}_{\mathrm{o} 2}$ : Rainfall descriptive indices are not averagely similar inspite of assumed common base.

\section{Findings and Discussion}

Trend analysis: A trend is the general pattern of fluctuation of data over time (OKOKO, 2001). Many methods are available for calculating trend but the most common ones are the least square regression techniques (Box and Jenkins, 1976). For reasons of hypothesis testing, generalization and projection, the study adopted the least square regression method.

Figures 2; 3 and 4 represent the line and least square composite graphs of the annual rainfall regimes for Uyo, Uwanhia and calabar. While the $y$-axes represent the annual rainfall amount in $\mathrm{mm}$, the $\mathrm{x}$-axes show time in years. Initial processing of the 35 year series station after station utilizing the basic filtering technique with the divergent bar graph indicates that, Uyo has been experiencing below average rain fall for 20 years. Moreso, the initial 10 years (1971-1980) experienced above average values at a stretch. This fluctuating and declining rainfall series for Uyo is statistically defined by the function.

$$
\bar{Y}=3191.23-36.16 x+\text { e. }
$$

It is significant at $99 \%$ confidence level with a coefficient of determination figure of 0.363 or $36.3 \%$. (Fig. 2).

The annual rainfall regime for Umuahia is similar to that of Uyo earlier discussed with 17 years recorded values above the mean value of $2403.8 \mathrm{~mm}$. For 23 years (1981-2004) the annual values are below the 35 year average. The fluctuating and declining temporal series is defined by the function.

$$
\overline{\mathrm{Y}}=2955.20-31.50 \mathrm{x}+\mathrm{e} \text { (fig. 3). }
$$

It is a statistically significant decline at $99 \%$ confidence level with percentage explanation of 0.535 or $53.5 \%$. Calabar appears different in terms of its fluctuation and trend with a rising trend and seemingly marked periodicity of about ten years return period. The series equation is shown as;

$$
\overline{\mathrm{Y}}=3678.75+9.95 \mathrm{x}+\mathrm{e}(\text { fig } 4)
$$

The trend though positive is statistically not significant at $99 \%$ confidence; percentage explanation is equally quite low at $6.91 \%$.

Spatial pattern: The distributional pattern of the annual rainfall can as well be understood after a comparative description of the baseline indices and hypothesis testing (table 1).

Variations in space of aspects of the rainfall climatology for the study area is presented in the Table 1 above. Being locations within the Equatorial climatic type, koppen's Af. classification, the mean value, range and the 35 year maximum values are expectedly very high, Table 1 refer. The annual minimum are equally high with a low coefficient of variability values indicative of a high incidence of the summer rains throughout the period of study. For objective conclusions regarding homogeneity and association of the statistics with a theoretical common 
base, the $\mathrm{K}$ - sample Chi-square test is utilized. Notice that the series variances are not included in the calculation. With the determination of the expected frequencies for each entry in Table 1, the usual Test statistic usually given as;-

$$
\begin{aligned}
& \mathrm{X}^{2}=\sum_{\mathrm{i}=1}^{\mathrm{n}} \frac{(\mathrm{O}-\mathrm{E})^{2}}{\mathrm{E}} \\
& \text { is utilized } \\
& \left.\left(\frac{2558-2602}{2602}\right)^{2}+\left(\frac{2403-2379}{2379}\right)^{2}+\frac{(2853-2834}{2834}\right)^{2} \\
& =45.47=0.24=0.12 \\
& \left.\left.\frac{(3825-3735}{3735}\right)^{2}+\frac{(3401-3414}{3414}\right)^{2}+\frac{(3992-4067)^{2}}{4067} \\
& =2.16=0.04=1.38 \\
& \left.\left.\left(\frac{1588-1764}{1764}\right)^{2}+\frac{(1599-1612}{16.12}\right)^{2}+\frac{(2110-1921}{1921}\right)^{2} \\
& =17.56=0.01=18.59 \\
& \left.\left(\frac{597-4752}{4752}\right)^{2}+\left(\frac{482-427}{427}\right)^{2}+\frac{(376-508}{508}\right)^{2} \\
& =3633=7.08=34.29 \\
& \left.\left.\left.\frac{(0.23-0.17}{0.17}\right)^{2}+\frac{(0.18-0.16}{0.16}\right)^{2}+\frac{(0.13-0.19}{0.19}\right)^{2} \\
& =0.02=0.00=0.01 \\
& X^{2}=45.47+0.24+0.12+2.16+0.04+1.38+17.56+0.10+18.59+3633+7.08+34.29+0.02+0.00+ \\
& 0.01 \\
& \mathrm{X}_{\mathrm{c}}^{2}=3759.96
\end{aligned}
$$

\section{Decision Rule}

Reject null hypothesis $\left(\mathrm{H}_{\mathrm{o}}\right)$ and accept the alternative research hypothesis $\left(\mathrm{H}_{\mathrm{i}}\right)$ if critical $\mathrm{x}^{2}$ value is lower than the calculated value at $99 \%$ confidence ie $\mathrm{x}^{2}>\mathrm{x}^{2}=$ reject $\mathrm{H}_{0}$.

\section{Decision}

At $99 \%$ confidence level and (number of rows -1$)$ (number of columns -1$)=(4-1)(3-1)=(3)(2)=6$ degrees of freedom, the calculated $x^{2}$ value is greater than the critical value i.e $\left(x^{2}>x^{2}=3759>16.8\right)$. The decision is that there is homogeneity among the series descriptive statistics having been derived from same climatic type

\section{Discussion}

Thirty five years (1971-2006) rainfall data for three locations in Humid South eastern Nigeria have been studied for spatial pattern and trend. Testable hypothesis on the issues have been formulated and tested to guide the discussions. For the period under study the annual rainfall regimes for Uyo and Umuahia appear to be varying and changing statistically. At $99 \%$ confidence significant declines in the temporal series have been established for the two locations mentioned. Calabar, on the other hand, appears different with increasing though statistically insignificant trend. Oceanic influences may largely explain the situation for calabar.

However the conclusions reached for Uyo and Umuahia after the trend analysis using the Least Square technique appear instructive in favour of the climate variability-global warming - climate change debates. Temporal variations are expected of natural systems but not persistently declining fluctuations over time as shown through the analysis; it is rather a fact that in the seventies, greenhouse gases emissions globally might not have been as intense and varied as in the late nineties. The annual rains for Uyo and Umuahia may have fluctuated more due to the vagaries in the dynamic meteorological factors such as the mean latitudinal location of the ITD and the strength of the moisture laden south-west trade wind in the sub-region (Adedokun, 1978; Adetolalu 1981; Anyadike 77). In the national sense, the seventies and eighties may be regarded as the start of industrialization, urbanization, population explosion with intense agricultural activities in Nigeria. About two decades after, these development indicators became intense and extensive with successive governments albeit corruption, devoting a greater percentage of budgetary allocations into the development of socio-economic infrastructures. The result of the scenarios painted above is the increasing emission of greenhouse gases into the regional atmosphere, global warming and changes in the annual rainfall regime (NIMET, 2006 IPCC). In support of the above explanations and conclusion, Afangideh et al; (2005) observed through a similar trend analysis of the annual rainfall and temperature for Uyo, South-eastern Nigeria, that the annual temperature trend tended to stagnate rising rise while 
the annual rainfall showed a declining trend. However the expected annual rainfall regime for Umuahia and Uyo, up to year 2015 and utilizing the series equations developed for theoretical and planning purposes are shown in table 2 below.

\section{Geographic pattern:}

Table 1, please refer, shows aspects of the mean annual rainfall spatial pattern for the sub-region. It encompasses the mean value, maximum and minimum values, the range, variance and the standard deviation. The indices above are considered high particularly the annual values, range and the series coefficient of variability having originated from an Equatorial Climatic type (Ojo 1981, Nieuwolt, 1980, Goh Cheng Leon and Adeleke, 1983). Statistical testing for homogeneity of data with the K-sample chi-squared test module is positive as the null hypothesis is rejected. The acceptance of the alternative hypothesis that the baseline climatologically indices are similar or homogenous is nevertheless enlightening. Calabar, Uyo and Umuahia are well within the Humid Tropical climatic type with atleast six months of summer precipitation, April - October with two distinct seasons, and under the influence of the South-west monsoon (Adejlalu 1981). Furthermore, the human influence on the climate through growths and development in urban infrastructures, high population density and fossil fuel consumption considered averagely same across the study space high provides yet another explanations for the statistical test conclusions. Other weather and climatic elements and characteristics viz-a-vis temperature, humidity, winds and visibility can thus be expected to be spatially similar. Theoretical values for the region as a whole have been determined and given below.

\section{Conclusions and Recommendations}

Whereas the study has established the annual rainfall characteristics through analysis of the spatial pattern for the Humid tropics, the temporal pattern suggests a fluctuating and significantly declining trend except for calabar. The temporal pattern in other words is not only expectedly varying but most surprisingly. Climate rainfall change is a global pandemic with negative prospects for Sub-Saharan Africa and elsewhere. If planned adaptive or mitigative initiatives are not initiated, the region and elsewhere is threatened in the long term. Moreover the pandemic becomes intense and widespread overtime (IPCC 1996, Rosenzweig et al, 1999) with developments in science, technology and human population.

A negative trend or decline in the annual rainfall regime may also be extended and viewed to encompass probable changes in the duration, intensity, frequency and the spread for the sub-region. These change response stimuli, including the rainfall amount, focused in the study (Smith et al 1999; Smith et al 2000; Rosenzweig and Parry 1994) constitute the entire components of rainfall changes that is potentially harmful to sensitive human systems in the long and short term. It is recommended therefore that follow-up studies aimed at identifying other response stimuli/lus other than the declining figures is required. Such a holistic approach may equally lead to a holistic solution to the pandemic. Capacity building of human operators of sensitive systems e.g. the agricultural and health sub-sectors etc be initiated by all governments as stitch-in-time measures. Amongst other things, the ability to respond or cope is known to be a function of the awareness level, income and education (Afangideh 2006). So greater awareness through education that seems totally lacking and skills through extension services education of peasants in particular need to be enhanced for informed and efficient reactions. Finally, an intergraded impact study to determine the multiple effect of human development on the annual rainfall regime is strongly advocated. Besides providing a scientific management framework through its modeling and projections, the integrated impact assessment approach normally suggests adaptation policy options (Fussel and Kein 2000).

\section{References}

Ayoade. (1986). Introduction to climatology for the tropics Ibadan.

Ademran Ojo. (1981). The weather and climates of West Africa Ibadan, Heinemann.

Adefolalu, D. D. (1981b). The weather and climate of calabar, a study of coastal micro - climatology in the equatorial tropics. Senate Research Grant Project, Geography Department, University of Calabar.

Adefolalu, D. O. (1981a). Main Tropospheric Features Over West Africa. Part 1; low level synoplic scale features during summer. J. I. Geogr, volume 4.

Adedokun, J. A. (1978). West African precipitation and dominant Atmospheric mechanism. Archv. Met. Geoph. Biokl, Ser. A. 27, 287-31D.

Adedokun J. A. (1979). Towards achieving an Intra season forecast of the West African Precipitation, Archv of Meti Geoph. Bioklino Ser. A. 28, 19-38.

Anyadike, R. N. C. (1977). West African Rainfall; its symoptic and dynamic climatology. (Unpublished Ph.D Dissert) University of Sheffield.

Afangideh A. I. (1989). The Aspects of the weather in little Dry season phenomenon of south-western Nigeria. Unpublished M.Sc thesis, Geogr. Dept. University of Ibadan, Nigeria.

Afangideh, A. I. (2005). The changing temperature and rainfall Amount in the Humid Tropical City of Uyo, AKS - Nig. African Journal of Environmental Pollution and Health, Vol. 4 No 2. 
Afangideh, A. I. (2006). Awareness and Response of Farmers to the changing Rainfall regime in parts of south-eastern, Nigeria, Unpublished Ph.D Dissert, Geography Dept. Uni-Uyo, Nigeria.

Afangideh, A. I., P. A. Akpan, Ekanem in Ekanem. (2008). Adaptive response strategy of farmers to changing rainfall averages in parts of south-eastern Nigeria. Africa focus, Vol. one, No 2, April 2008.

Afangideh, A. I., Edet, E. O. Ekanem, E. M. (2008). An analysis of the trend in Annual Rainfall Dynamics for the Humid tropics, a case study of calabar, CRS, Nigeria. Neoafricanists Review, Vol. II, No 1, 2008.

Afangideh, A. I., Ekanem, M. E. and Udofia, E. P. (2004). Rainfall Climatology and Hydroelectric power generation, a case study of Kainji Hydro Electric power station, Nigeria. Nigerian jour of social and development issues, Vol 4, No 1, Jan 2004.

Box, GEP and Jenkins, G. M. (1976). Time series Analysis Forecasting and control. San Francisco, Holder Day Publishers.

Kates, R. W. (1997). Climate change 1995 - Impacts, Adaptation and mitigation, Environment 39 (9), 29 - 33.

Kane, S. M.; J. Reilly and J. Tobey. (1992). An empirical study of the economic effects of climate change on world agriculture. Climate change, 21, 17-35.

Gregory, S. (1980). Statistical methods and the Geographer $\left(4^{\text {th }}\right.$ Ed). London Longman.

Nimet. (2007). Nigeria Climate Review Bulletin. Nigeria Met. Agency No 001.

Okoko, E. (2001). Quantitative techniques in urban analysis. Ibadan, Krafy Books.

Ojo O. (1977). Weather and climates of West Africa. Ibadan Heinemann.

IPCC. (1996). Climate change impact, adaptations and Mitigation. Cambridge, CUP.

Smit, B. I. Burton, R. J. T. Klein and R. Street. (1999). The science of Adaptation; a framework for assessment; mitigation and Adaptation strategies for global change 4, 199-213.

Smit, B. I., Burton, R. J. T. Klein and J. Wandel. (2000). An Anotomy of adaptation to climate change and variability; climate change 45, 223-251.

Rosenzweig, C. and M. L. Parry. (1999). Potential impact of climate change on world food supply. Nature 367, 133-138.

Udofia, E. P. (2008). Fundamentals of social science statistics, Enugu, Immaculate. Books.

World Bank. (1994). The world development report; Development and the environment, Washington.

WMO. (1988). Water Resources and Climate Change; Sensitivity of Water Resource Systems to climate change and variability. WCAP-4, WMO, Gemera.

Table 1. Rainfall descriptive indices for selected towns in south east Nigeria

\begin{tabular}{|l|l|l|l|l|}
\hline $\mathrm{S} / \mathrm{N}$ & Descriptive index & Uyo & Umuahia & Calabar \\
\hline 1 & Mean value & $2558.2 \mathrm{~mm}$ & $2403.8 \mathrm{~mm}$ & $2853.0 \mathrm{~mm}$ \\
\hline 2 & Maximum & $3825.4 \mathrm{~mm}$ & $3401.7 \mathrm{~mm}$ & $3992.5 \mathrm{~mm}$ \\
\hline 3 & Minimum & $1588.4 \mathrm{~mm}$ & $1599.4 \mathrm{~mm}$ & $2110 \mathrm{~mm}$ \\
\hline 4 & Standard deviation & $597.8 \mathrm{~mm}$ & $428.9 \mathrm{~mm}$ & $376.8 \mathrm{~mm}$ \\
\hline 5 & Variance & $357368.3 \mathrm{~mm}$ & $183955.1 \mathrm{~mm}$ & $141986.8 \mathrm{~mm}$ \\
\hline 6 & Coefficient of variability & $0.23 \mathrm{~mm}$ & $0.18 \mathrm{~mm}$ & $0.13 \mathrm{~mm}$ \\
\hline 7 & Range & $2237 \mathrm{~mm}$ & $1802.3 \mathrm{~mm}$ & $1882.5 \mathrm{~mm}$ \\
\hline
\end{tabular}

Table 2. Projected rainfall figures for Uyo and Umuahia, Southern-eastern, Nigeria

\begin{tabular}{|l|l|l|}
\hline \multicolumn{3}{|c|}{ Amount in mm } \\
\hline Year & Uyo & Umuahia \\
\hline 2007 & $1890 \mathrm{~mm}$ & $1821.2 \mathrm{~mm}$ \\
\hline 2008 & $1854 \mathrm{~mm}$ & $1790.2 \mathrm{~mm}$ \\
\hline 2009 & $1817 \mathrm{~mm}$ & $1758 \mathrm{~mm}$ \\
\hline 2010 & $1781 . \mathrm{mm}$ & $1729 \mathrm{~mm}$ \\
\hline 2011 & $1745 \mathrm{~mm}$ & $1695 \mathrm{~mm}$ \\
\hline 2012 & $1709 \mathrm{~mm}$ & $1664 \mathrm{~mm}$ \\
\hline 2013 & $1673 \mathrm{~mm}$ & $1632 \mathrm{~mm}$ \\
\hline 2014 & $1636 \mathrm{~mm}$ & $1601 \mathrm{~mm}$ \\
\hline 2015 & $1600 \mathrm{~mm}$ & $1569 \mathrm{~mm}$ \\
\hline
\end{tabular}


Table 3. Theoretical description rainfall climatological indices for South-eastern Nigeria

\begin{tabular}{|l|l|l|}
\hline & Mean value & Range \\
\hline Mean value & $2609 \mathrm{~mm}$ & $449.2 \mathrm{~mm}$ \\
\hline Maximum & $3739.86 \mathrm{~mm}$ & $490.8 \mathrm{~mm}$ \\
\hline Minimum & $1765.93 \mathrm{~mm}$ & $521.6 \mathrm{~mm}$ \\
\hline Standard deviation & $467.83 \mathrm{~mm}$ & $221 \mathrm{~mm}$ \\
\hline Variance & $227770 \mathrm{~mm}$ & $215381.5 \mathrm{~mm}$ \\
\hline Coefficient of variation & 0.18 & 0.1 \\
\hline
\end{tabular}
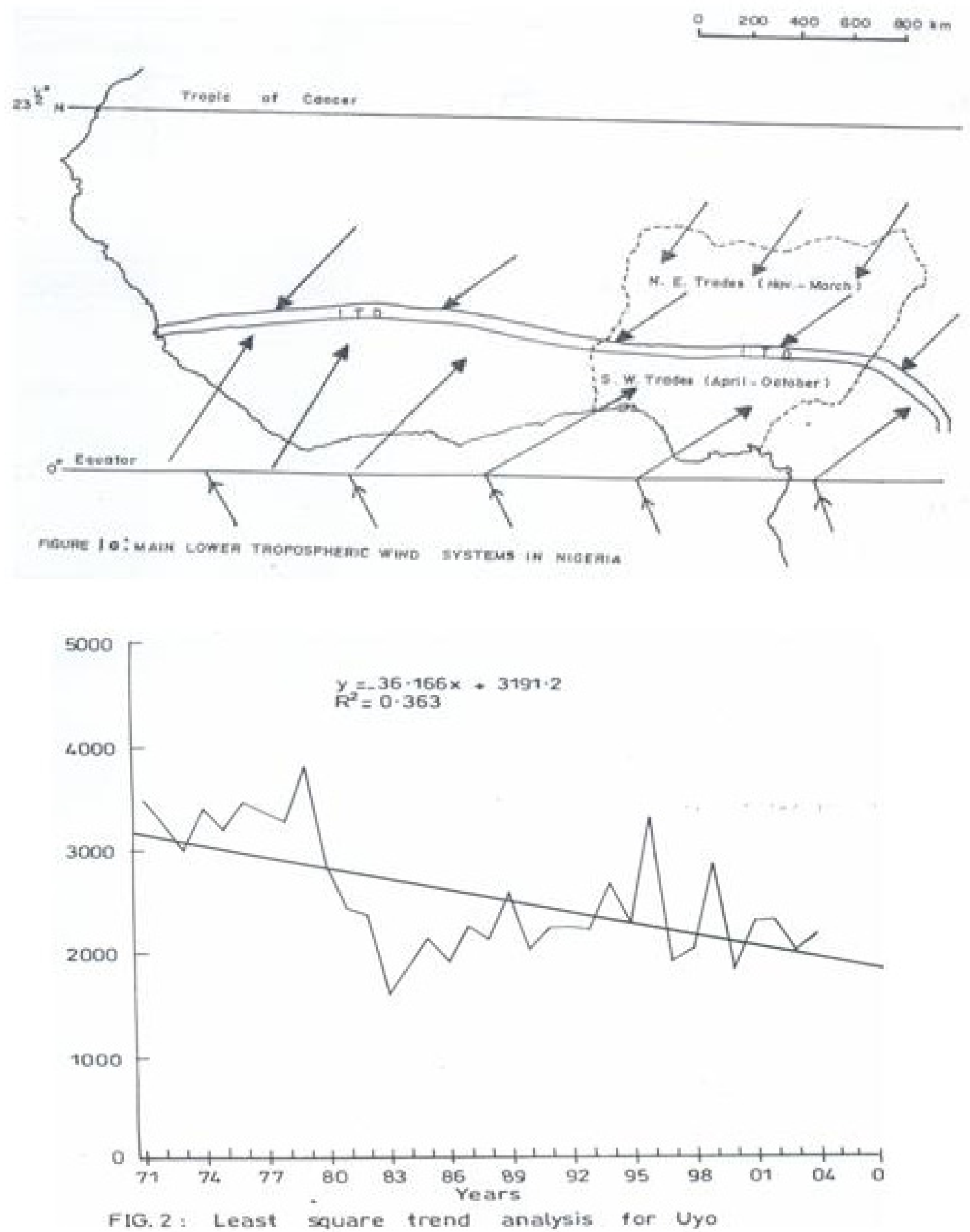


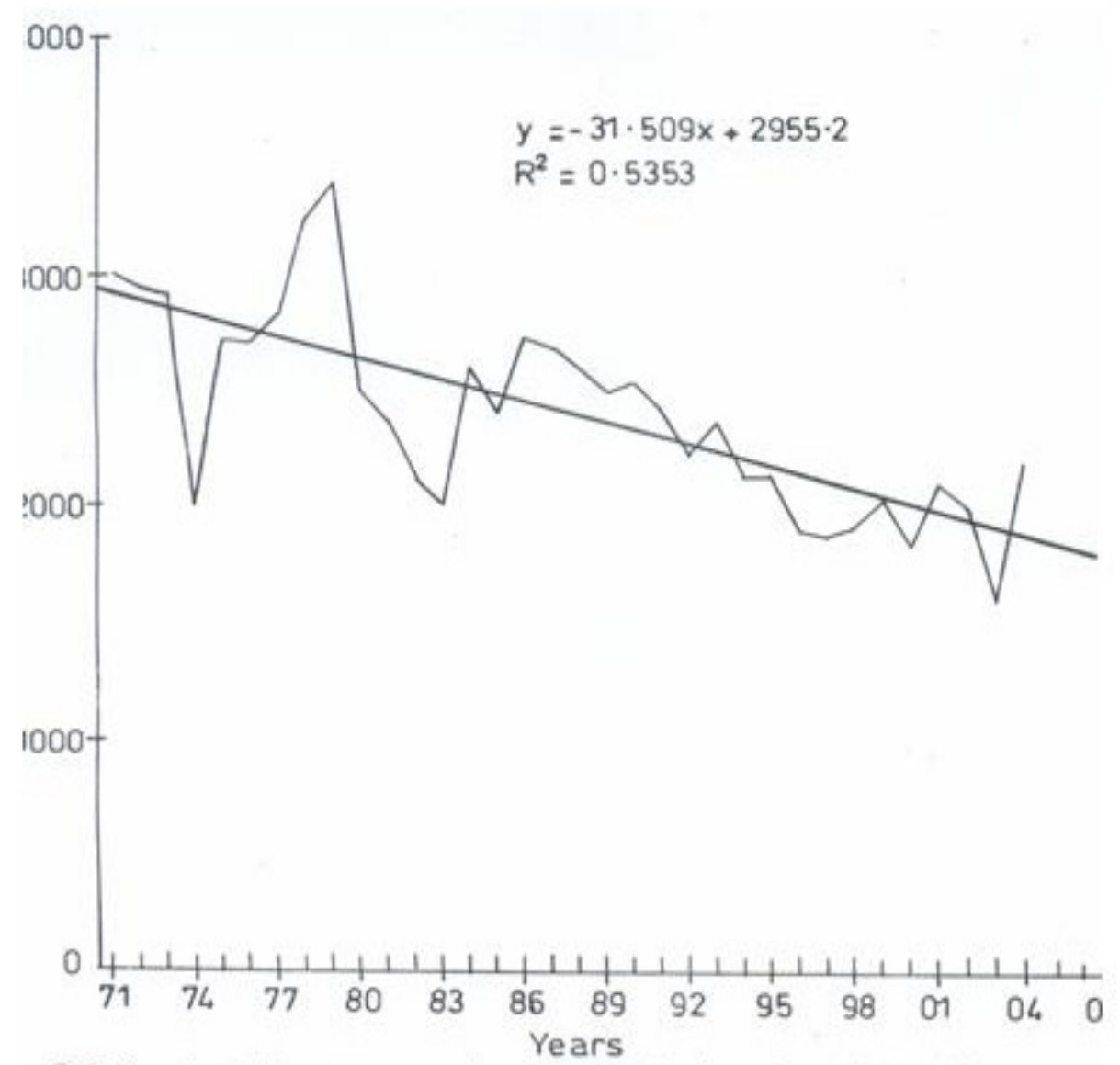

FIG.3: Least square trend analvsis for Umuahia

Curve Fit

Model : Mod.3

Independent : Year

Dependent Mth Rsq d.t. F Sigf bo bl

$\begin{array}{lllllll}\text { Calabar LIN } & 069 & 32 & 2.38 & .133 & 2676.75 & 9.9562\end{array}$

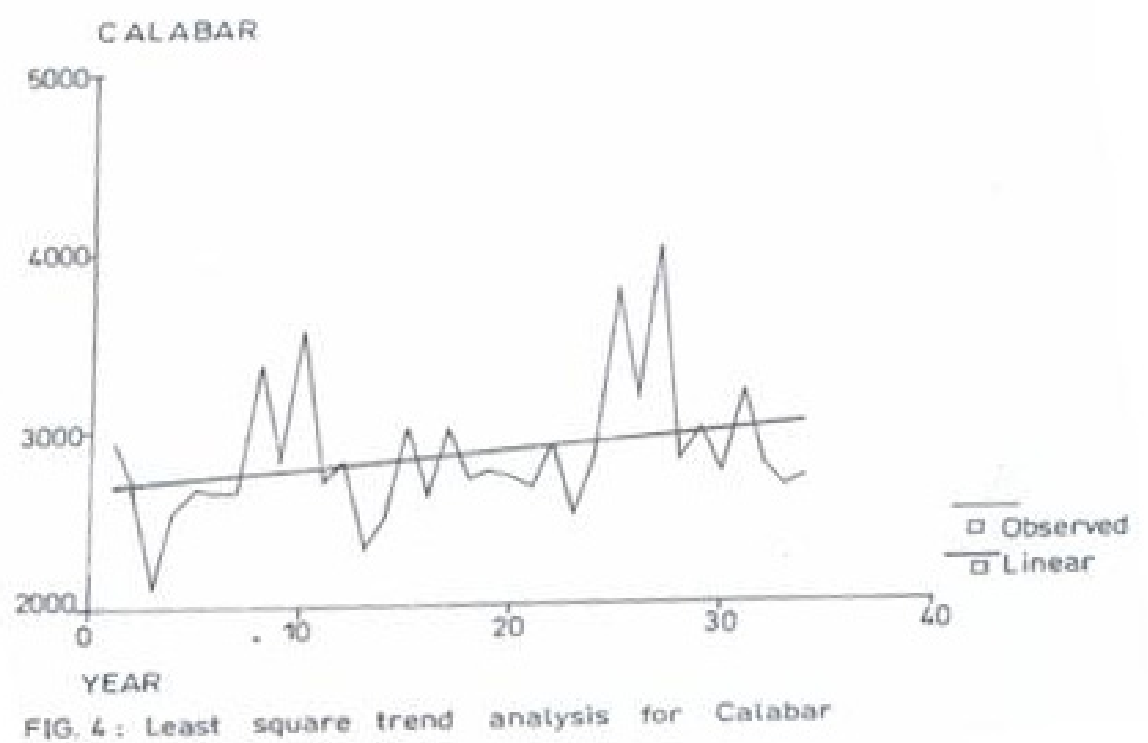

